\title{
Linking long-term changes of zooplankton community to environmental variability at the EPEA station (Southwestern Atlantic Ocean)
}

\author{
María Delia Viñas ${ }^{1,2,}$, Georgina D. Cepeda ${ }^{1,2}$ and Moira Luz Clara ${ }^{1,2,3}$ \\ ${ }^{1}$ Instituto Nacional de Investigación y Desarrollo Pesquero (INIDEP), Paseo Victoria Ocampo No 1, Escollera Norte, B7602HSA - Mar del \\ Plata, Argentina. ${ }^{2}$ Instituto de Investigaciones Marinas y Costeras (IIMyC-CONICET), Facultad de Ciencias Exactas y Naturales, Universidad \\ Nacional de Mar del Plata (UNMdP), Consejo Nacional de Investigaciones Científicas y Técnicas (CONICET), Argentina. ${ }^{3}$ Instituto Franco- \\ Argentino para el Estudio del Clima y sus Impactos (CNRS-IRD-CONICET-UBA; IRL 3351 IFAECI). Buenos Aires, Argentina. \\ ORCID María Delia Viñas (D) https://orcid.org/0000-0003-2824-4405, Georgina D. Cepeda (D) https://orcid.org/0000-0002-8234-6763, \\ Moira Luz Clara (D) https://orcid.org/0000-0002-7539-5292
}

Marine and Fishery Sciences MAFIS

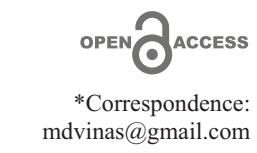

Received: 30 April 2021 Accepted: 16 June 2021

ISSN 2683-7595 (print) ISSN 2683-7951 (online)

https://ojs.inidep.edu.ar

Journal of the Instituto Nacional de Investigación y Desarrollo Pesquero (INIDEP)

This work is licensed under a Creative Commons AttributionNonCommercial-ShareAlike 4.0 International License

\begin{abstract}
A significant sea surface temperature increase has been reported for the Southwestern Atlantic Ocean between $20^{\circ} \mathrm{S}-50^{\circ} \mathrm{S}$ over the last decades. Zooplankton organisms are highly sensitive to temperature rise. They play a very important role in marine ecosystems by providing the main pathway of energy transfer from primary producers to consumers. Seasonal and interannual (2000-2017) variability of metazooplankton in relation to environmental changes, particularly temperature, were analyzed at the EPEA station ( $\left.38^{\circ} 28^{\prime} \mathrm{S}-57^{\circ} 41^{\prime} \mathrm{W}\right)$. Copepods, appendicularians, cladocerans, chaetognaths, and lamellibranch larvae were identified and quantified. Temperature exhibited a positive interannual trend during the series, whereas the Simpson parameter showed a decreasing tendency and salinity remained almost constant. Adults, copepodites, and nauplii of small copepods belonging to Oithonidae (mostly Oithona nana) and Paracalanidae-Clausocalanidae families dominated the metazooplankton community during the study period. Three groups of taxa with different seasonal patterns of variability were clearly identified. Members of Oithonidae exhibited positive interannual trends, whereas lamellibranch larvae and Calanidae showed negative interannual trends. A direct influence of temperature anomaly on these changes is suggested as well as possible indirect effects of this anomaly upon zooplankton through different phytoplankton fractions. Under the current scenario of climate change, the maintenance of this time-series becomes crucial in order to evaluate the eventual transfer of the environmental variability to the local food webs through planktonic organisms.
\end{abstract}

Key words: Microzooplankton, mesozooplankton, time-series, EPEA station, Buenos Aires shelf, Southwestern Atlantic.

Relación entre los cambios a largo plazo de la comunidad de zooplancton y la variabilidad ambiental en la estación EPEA (Océano Atlántico Sudoccidental)

RESUMEN. En las últimas décadas se ha registrado un aumento significativo de la temperatura superficial del mar en el Océano Atlántico Sudoccidental, entre $20^{\circ} \mathrm{S}-50^{\circ} \mathrm{S}$. Los organismos del zooplancton son muy sensibles al aumento de la temperatura. Ellos cumplen un rol muy importante en los ecosistemas marinos dado que constituyen la principal vía de transferencia de energía desde los productores primarios a los consumidores. En este trabajo se analizó la variabilidad estacional e interanual (2000-2017) del metazooplancton en la estación EPEA ( $\left.38^{\circ} 28^{\prime} \mathrm{S}-57^{\circ} 41^{\prime} \mathrm{W}\right)$, en relación con los cambios ambientales, en particular de la temperatura. Copépodos, apendicularias, cladóceros, quetognatos y larvas de lamelibranquios fueron identificados y cuantificados. La temperatura exhibió una tendencia interanual positiva de las anomalías durante la serie mientras que el parámetro de 
Simpson mostró una tendencia decreciente y la salinidad prácticamente se mantuvo invariable. Adultos, copepoditos, y nauplii de los copépodos pequeños pertenecientes a las familias Oithonidae (en su mayoría Oithona nana) y Paracalanidae-Clausocalanidae dominaron la comunidad del metazooplancton durante el período de estudio. Se identificaron claramente tres grupos de taxa con diferentes patrones estacionales de variabilidad. Miembros de la Familia Oithonidae exhibieron tendencias interanuales positivas mientras que las larvas de lamelibranquios y la Familia Calanidae mostraron tendencias interanuales decrecientes. Se sugiere un efecto directo de las anomalías de la temperatura sobre estas variaciones así como posibles efectos indirectos de este parámetro sobre el zooplancton, a través de su influencia sobre diferentes fracciones del fitoplancton. En el actual escenario de cambio climático, el mantenimiento de esta serie temporal es de gran importancia para evaluar la transferencia eventual de la variabilidad ambiental a la trama trófica local a través del plancton.

Palabras clave: Microzooplancton, mesozooplancton, serie temporal, estación EPEA, plataforma bonaerense, Atlántico Sudoccidental.

\section{INTRODUCTION}

Since the beginning of the twentieth century, our planet has been experiencing a gradual increase of the mean global temperature, with an intensification of the warming rate over the last decades (IPCC 2019).

An analysis of time series of satellite sea surface temperatures (SST) carried out in the South Atlantic Ocean during the last 30 years prior to 2012 indicated a SST increase in almost $86 \%$ on this region (Muller-Karger et al. 2017). However, whereas in the north Argentine continental shelf, areas of significant increase of surface temperature were observed between $20^{\circ} \mathrm{S}-50^{\circ} \mathrm{S}$, others with a cooling trend were registered in latitudes of $49^{\circ} \mathrm{S}-52^{\circ} \mathrm{S}$ in the south Patagonian shelf (Risaro 2020).

Water temperature and salinity are excellent indicators of the physical environment in which plankton are living, affecting them both directly (i.e., through physiology and growth rates) and indirectly (i.e., through water column stratification and related nutrient availability) (O'Brien et al. 2013).

Marine zooplankton communities are highly diverse and thus perform a variety of ecosystem functions (Richardson 2008 and references within). The most important role of these organisms is to act as major grazers in food-webs by providing the principal pathway for energy from primary producers to consumers at higher trophic levels.
Zooplankton can be, moreover, recognized as beacon of climate change for several reasons (Richardson 2008). Because of their physiology and short live cycles, zooplanktonic species are highly sensitive to temperature rise (Mauchline 1998; Edwards and Richardson 2004; Beaugrand and Kirby 2018). Therefore, present climate changes may strongly affect their population dynamics and phenology (Hays et al. 2005; Rice and Stewart 2016). As these organisms are generally not commercially exploited, their long-term trends of variability are mostly due to environmental changes (Richardson 2008).

Sustained ocean time-series, particularly shipbased repeated measurements, represent one of the most valuable tools to characterize and quantify ocean ecosystem cycles and fluxes, from the plankton up to higher trophic levels, and their association to changing climate (Edwards et al. 2010; Valdés and Lomas 2017). Time-series observations over multiple decades are necessary to differentiate between natural and anthropogenic variability (O'Brien et al. 2017 and references within).

In the northern coastal waters of Argentina $\left(38^{\circ} 28^{\prime} \mathrm{S}-57^{\circ} 41^{\prime} \mathrm{W}\right)$ (Figure 1), a biogeochemical time-series was established at the EPEA station (Estación Permanente de Estudios Ambientales/Permanent Station of Environmental Studies), as part of the DIPLAMCC (Dinámica del Plancton Marino y Cambio Climático/Dynamics of Marine Plankton and Climate Change) Project of INIDEP (Instituto Nacional de Investigación y Desarrollo Pesquero). Several chemical, physical, 
photo-biological, and planktonic variables are monitored there on a monthly basis since 2000. In this coastal station, phytoplankton community reaches its maximum biomass in winter, mainly represented by $20-200 \mu \mathrm{m}$ diatoms of the microphytoplankton fraction (Negri and Silva 2011). Ultraphytoplankton fraction $<5 \mu \mathrm{m}$ makes its major contribution to total biomass in summer, thus configuring an oligotrophic-like ecosystem (Silva et al. 2009; Negri and Silva 2011; Viñas et al. 2013). The first approach to analyze phytoplankton dynamics at the EPEA station in an interannual scale (2000-2009) indicated an increasing trend in chlorophyll concentrations during the last years of the study period, mainly due to the contribution of the smallest phytoplankton size fraction, i.e. the picophytoeukariotic organisms (Silva 2011). The proliferation of these organisms due to climatic variations has been reported on a large scale ( $\mathrm{Li}$ and Harrison 2008; Moran et al. 2010) highlighting the increasing importance of small phytoplankton in a future global warming scenario (Sarmiento et al. 2004; Behrenfeld et al. 2006).
Considering the zooplankton community, Diovisalvi (2006), Temperoni et al. (2011), Cepeda (2013) and Viñas et al. (2013) analyzed the annual cycle of abundance, size structure, and biomass of its main components at the EPEA station, whereas Daponte et al. (2004) and Capitanio et al. (2008) focused particularly on chaetognaths and appendicularians, respectively. Small-sized copepods ( $<1 \mathrm{~mm}$ total length) dominated by Oithona nana and members of Paracalanidae constitute the bulk of the metazooplankton (81\%) throughout the year in the EPEA station with maximum values in summer in terms of abundance and biomass (Viñas et al. 2013). It is known that the reproductive cycle of small copepods in temperate seas (Pittois et al. 2009) is positively controlled by temperature (Viñas 1990; Uye and Shibuno 1992; Temperoni et al. 2011).

The present work shows an analysis of the interannual patterns of variability of main components of metazooplankton and their relationship with physical cues carried out for the first time at the EPEA station between March 2000 and November 2017 (18 years). The concurrent analy-

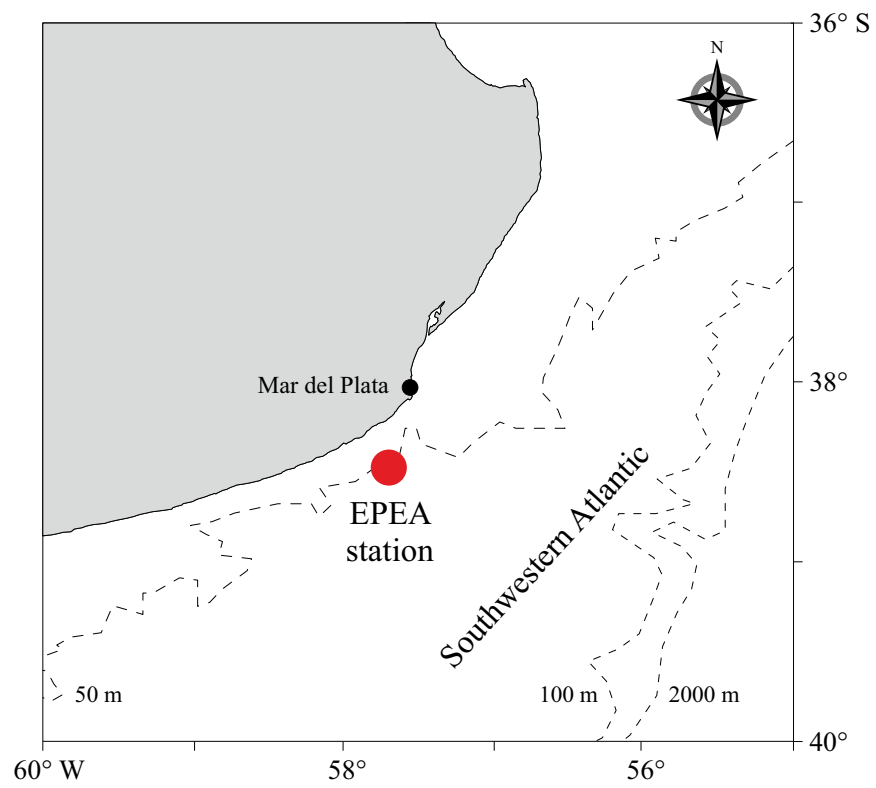

Figure 1. Location of the EPEA station $\left(38^{\circ} 28^{\prime} \mathrm{S}-57^{\circ} 41^{\prime} \mathrm{W}\right)$. 
sis of seasonal patterns of zooplankton abundance in relationship to the environmental factors will contribute to the interpretation of changes observed in the long-term scale. We hypothesized that during the studied period, under a scenario of Climate Change with increasing of both sea surface temperature and smallest phytoplankton size fraction concentration, a rise in the abundance of small copepod species is to be expected.

\section{MATERIALS AND METHODS}

\section{Hydrography}

During each cruise to the EPEA station, conductivity and temperature profiles were obtained with a Seabird CTD (SBE19) 01 CTD. Data were processed, quality checked, and stored in the Regional Oceanographic Database (BaRDO) at the Physical Oceanography Laboratory of INIDEP.

\section{Zooplankton sampling and laboratory analy- sis}

A total of 93 zooplankton samples were obtained with a small Bongo net (67 and $220 \mu \mathrm{m}$ meshes) equipped with flowmeters in each mouth for calculation of the filtered water volume. The net was obliquely trawled through the water column from $5 \mathrm{~m}$ of the bottom (48 $\mathrm{m}$ depth) to the surface. Tows were short (towing time: $2 \mathrm{~min}$; towing rate: $20 \mathrm{~m} \mathrm{~min}^{-1}$ ) with the ship moving at 2 knots speed. After obtained, samples were immediately preserved in 4\% formaldehyde solution. For the present study, only samples from the finest mesh net were analyzed considering the strong dominance of microzooplankton and mesozooplankton smaller than $1 \mathrm{~mm}$ total length previously reported at this station (Viñas et al. 2013) and the adequacy of this mesh size to retain them (Di Mauro et al. 2009).
Zooplankton components were identified under stereoscopic microscopy and grouped into the following categories:

- Oithonidae (OIT): includes adult and copepodite stages of $O$. nana and $O$. aff. helgolandica.

- Oithonidae (OITN): includes nauplii of $O$. nana and $O$. aff. helgolandica.

- Paracalanidae-Clausocalanidae (PACL): includes adult and copepodite stages of Paracalanus parvus, Parvocalanus scotti and Ctenocalanus spp.

- Paracalanidae-Clausocalanidae (PACLN): includes nauplii of Paracalanus parvus, Parvocalanus scotti and Ctenocalanus spp.

- Calanidae (CAL): includes only adult and copepodite stages of Calanoides carinatus.

- Evdne nordmanni (ENO).

- Penilia avirostris (PAV).

- Appendicularians (APP).

- Chaetognaths (CHA).

- Lamellibranchs larvae (LLA).

The number of individuals per cubic meter (ind. m-3) for each category was estimated from the counts of individuals in different aliquots of the original sample and the filtered volume by the net. The aliquot size of each taxon was established according to its original concentration in the sample.

\section{Data analysis}

Considering that the zooplankton sampling was performed obliquely through a portion of the water column, mean temperature (MT) and mean salinity (MS) were measured taking into account the maximum depth attained by the net. To determine the location of the transition between stratified waters and mixed waters, the stability Simpson parameter $(\varphi)$ was estimated (Simpson 1981). This is a measure of the mechanical work required to vertically mix the water column. Small values of $\varphi$ indicate 
poorly stratified waters while high values are associated with stratified ones. In this work, the value of $40 \mathrm{~J} \mathrm{~m}^{-3}$ was used as the limit between homogeneous $(\varphi<40)$ and stratified $(\varphi>40)$ waters, as established by Sabatini and Martos (2002).

Analyses of both seasonal and interannual variability were performed on the zooplankton data and then related with changes in physical data (MT, MS, and $\varphi$ ).

As with other time-series worldwide, sampling at the EPEA station exhibited irregularity in timefrequency. This fact was recurrent in the timeseries and calculation of an annual average of zooplankton abundance can be greatly influenced by time of sampling. This problem is further compounded by missing months within sampling years. Mackas et al. (2001) proposed a solution to this difficulty in which the annual anomaly is calculated as an average of individual monthly anomalies. This method, adopted by the Working Group on Zooplankton Ecology (WGZE) of ICES, reduces many of the issues of low frequency and/or irregular sampling and also removes seasonal signal from the year-to-year analysis (O’Brien et al. 2008). In order to estimate interannual and seasonal anomalies of physical and biological variables in the EPEA time-series, the method of Mackas et al. (2001) was used.

For seasonal analysis, the year was divided into four periods of three months each, starting in January for summer. Kruskal-Wallis non-parametric test was employed to compare abundances by seasons in view of the non-normality of the data. Before data analysis, the outliers of each taxonomic category were estimated considering the mean $\pm 1.96 \mathrm{SD}$ of its abundance and eliminating all minor or major values from the database. This procedure was applied for each season considered separately. After that, $\log (\mathrm{x}+1)$ transformation was applied to the remaining data.

A Principal Component Analysis (PCA) was employed to identify patterns in the data set corresponding to the original variables (zooplankton categories). Correlations among the biological variables and between these and the physical ones were used to interpret the grouping patterns produced by PCA. Analyses were performed employing Statistica v7 software (StatSoft Inc. 2007).

\section{RESULTS}

\section{Hydrography}

Temperature varied seasonally, with minima in winter (10.93 $\pm 0.85{ }^{\circ} \mathrm{C}$, July-September), and maxima in summer $\left(19.20 \pm 0.88{ }^{\circ} \mathrm{C}\right.$, JanuaryMarch) (Table 1). Salinity did not exhibit a clear seasonal variation and values fluctuated between $33.74 \pm 0.14$ in spring (October-December) and $33.94 \pm 0.15$ in autumn (April-June). Vertical stratification, quantified by $\varphi$, was more accentuated in summer (50.42 \pm 44.23$)$ and spring (23.50 $\pm 23.52)$ than in autumn $(4.26 \pm 11.72)$ and winter $(2.63 \pm 2.61)$. Mixing of water column, typical of the winter months, was reflected in the lowest value of $\varphi$ recorded during this season.

Table 1. Mean seasonal values \pm SD of MT, MS and $\varphi$ at the EPEA station during the period 2000-2017.

\begin{tabular}{lccc}
\hline Season & MT & MS & $\varphi$ \\
\hline Summer (J-F-M) & $19.20 \pm 0.88$ & $33.76 \pm 0.24$ & $50.42 \pm 44.23$ \\
Autumn (A-M-J) & $15.71 \pm 2.12$ & $33.94 \pm 0.15$ & $4.26 \pm 11.72$ \\
Winter (J-A-S) & $10.93 \pm 0.85$ & $33.89 \pm 0.13$ & $2.63 \pm 2.61$ \\
Spring (O-N-D) & $13.71 \pm 2.26$ & $33.74 \pm 0.14$ & $23.50 \pm 23.52$ \\
\hline
\end{tabular}


Interannual anomalies were analyzed in physical parameters during the study period. Whereas temperature displayed an increasing trend, Simpson parameter showed a decreasing tendency, and salinity did not show any important variation (Figure 2).

\section{Zooplankton}

\section{Composition and seasonal abundance}

Microzooplankton was dominated by nauplii of copepods and lamellibranch larvae (Table 2). Within the mesozooplankton, adults and copepodites of small copepods $(<1 \mathrm{~mm})$, represented mostly by Oithonidae and members of Paracalanidae-Clausocalanidae, dominated throughout the year, alternating their preeminence among seasons (Table 2; Figure 3). Thus, the dominance of Oithonidae was higher in spring and winter. On the contrary, Paracalanidae-Clausocalanidae predominated upon Oithonidae in summer and autumn. Appendicularians were also abundant all year round followed by cladocerans. Calanidae and chaetognaths were the less abundant taxa.

Adult and copepodite stages of Oithonidae attained their highest abundance in spring with a mean of 11,293 ind. $\mathrm{m}^{-3}$, followed by a mean of 7,159 ind. $\mathrm{m}^{-3}$ in summer (Table 2). Minimum
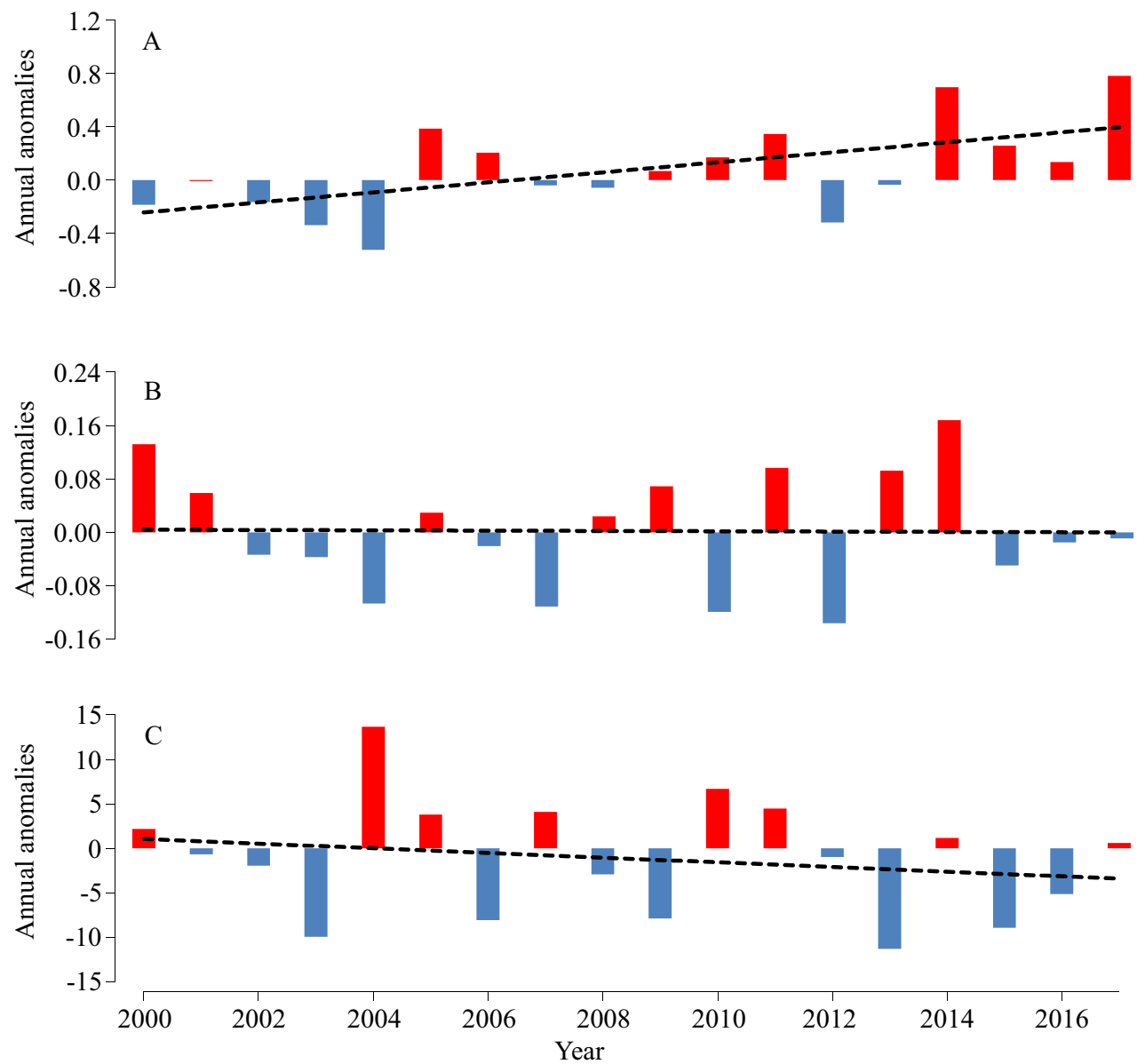

Figure 2. Annual anomalies of mean temperature (A), mean salinity (B) and $\varphi(C)$ at the EPEA station during the period 20002017. Dashed line: ns. trend. 


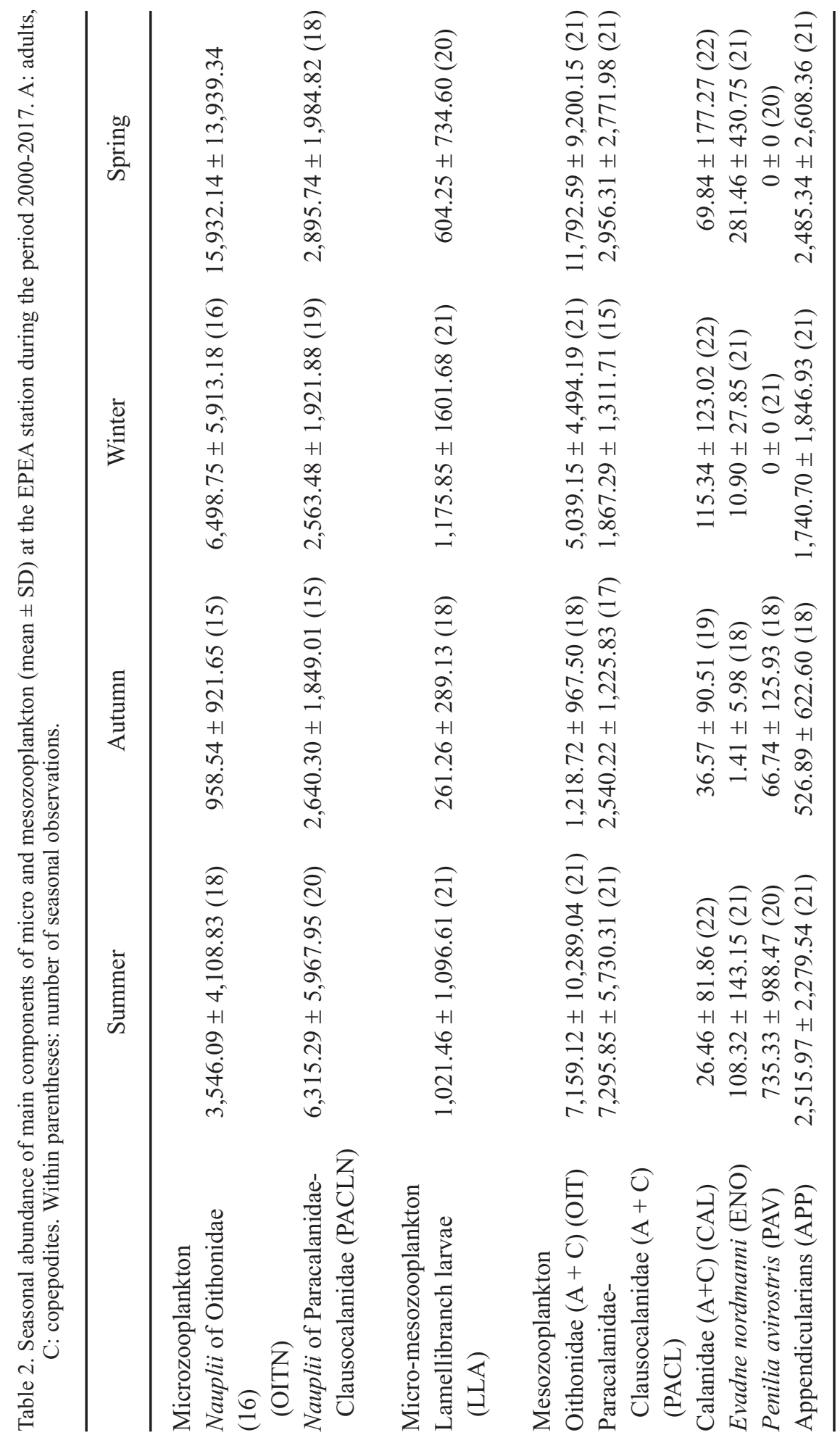




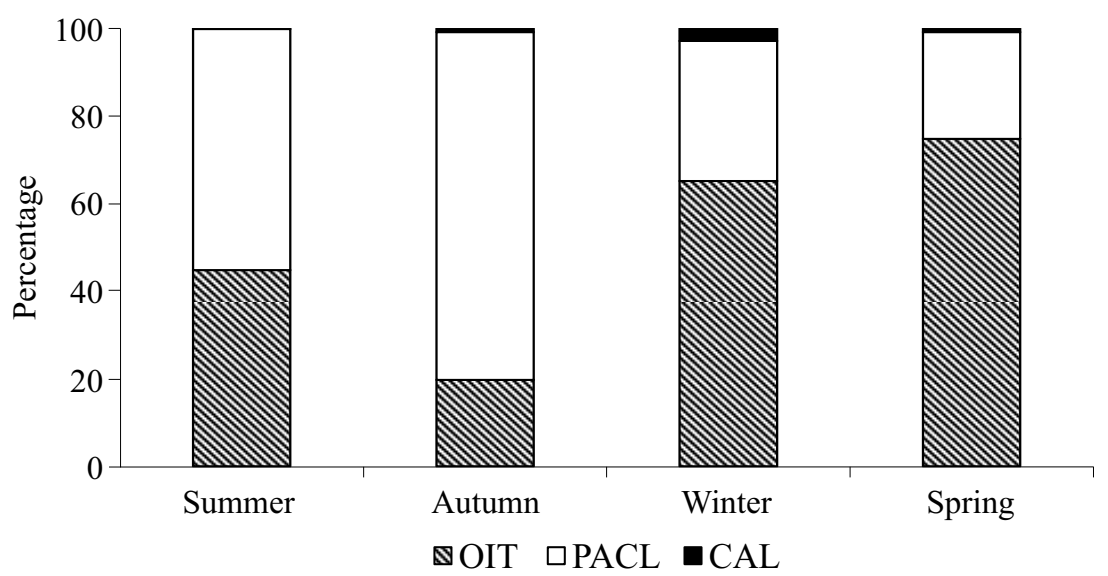

Figure 3. Mean seasonal percentages of contribution of OIT, PACL and CAL to copepods abundance at the EPEA station during the period 2000-2017.

occurred in autumn $\left(1,219\right.$ ind. $\left.\mathrm{m}^{-3}\right)$ which differed significantly from others seasons (Kruskal Wallis test, $\left.\mathrm{H}_{(3, \mathrm{~N}=81)}=26.08 ; \mathrm{p}=0.000\right)$. Similarly, nauplii of Oithonidae exhibited a clear increase of abundances from winter onwards with the highest densities occurring in spring $\left(15,932\right.$ ind. $\left.\mathrm{m}^{-3}\right)$, a gradual decrease in summer $\left(3,546\right.$ ind. $\left.\mathrm{m}^{-3}\right)$ and minimum (958 ind. $\mathrm{m}^{-3}$ ) in autumn (Table 2). Highly significant differences $\left(\mathrm{H}_{(3, \mathrm{~N}=65)}=29.69\right.$; $\mathrm{p}=.0000$ ) among seasonal abundances were recorded for these nauplii. Autumn was significantly different from winter and spring, while the latter differed from summer $(\mathrm{p}<0.01)$.

The highest abundance $\left(7,296\right.$ ind. $\left.\mathrm{m}^{-3}\right)$ of adults and copepodites of Paracalanidae-Clausocalanidae was registered in summer $\left(7,296\right.$ ind. $\left.\mathrm{m}^{-3}\right)$ and the lowest in winter $\left(1,867\right.$ ind. $\left.\mathrm{m}^{-3}\right)$, exhibiting significant differences among seasons $\left(\mathrm{H}_{(3, \mathrm{~N}=80)}=18.68 ; \mathrm{p}=.0003\right)$. Summer significantly differed from winter and spring $(\mathrm{p}<0.05)$ (Table 2, Figure 5 A). Although nauplii of Paracalanidae-Clausocalanidae showed also the highest values in summer $\left(6,315\right.$ ind. $\left.\mathrm{m}^{-3}\right)$, non-significant differences were observed among seasons $\left(\mathrm{H}_{(3, \mathrm{~N}=72)}=4.230 ; \mathrm{p}=0.24\right)$.

Among the Calanidae ( $>2 \mathrm{~mm})$, Calanoides carinatus was the only identified species. It was very scarce all around the year exhibiting the highest abundance in winter (115 ind. $\mathrm{m}^{-3}$ ) and the lowest one in summer ( 82 ind. $\mathrm{m}^{-3}$ ) (Table 2). Significant dissimilarities among seasons were documented for this species $\left(\mathrm{H}_{(3, \mathrm{~N}=85)}=20.23\right.$; $\mathrm{p}=.0002)$, with winter differing from summer and spring $(\mathrm{p}<0.05)$.

The abundance of lamellibranch larvae showed the highest seasonal value in winter $\left(1,176\right.$ ind. $\left.\mathrm{m}^{-3}\right)$, another minor peak in summer $\left(1,021\right.$ ind. $\left.\mathrm{m}^{-3}\right)$, and the lowest value in autumn (261 ind. $\mathrm{m}^{-3}$ ) (Table 2). This group showed significant seasonal differences $\left(\mathrm{H}_{(3, \mathrm{~N}=80)}=8.95 ; \mathrm{p}=.0299\right)$ in general, but no significant differences were detected between pairs of seasons.

Among cladocerans, E. nordmanni presented the peak of abundance in spring with 281 ind. $\mathrm{m}^{-3}$ and the minimum in autumn (1.4 ind. $\left.\mathrm{m}^{-3}\right)$ with significant seasonal differences $\left(\mathrm{H}_{(3, \mathrm{~N}=81)}=27.89\right.$; $\mathrm{p}=0.0000)$. Autumn was dissimilar from summer $(\mathrm{p}<0.05)$ and spring $(\mathrm{p}<0.001)$ and the latter differed from winter $(\mathrm{p}<0.005)$ (Table 2; Figure 7 A). P. avirostris was absent in winter and spring and was more abundant in summer (735 ind. $\mathrm{m}^{-3}$ ) (Table 2). Significant differences among seasons were detected $\left(\mathrm{H}_{(3, \mathrm{~N}=79)}=47.77 ; \mathrm{p}=.0000\right)$, with summer differing from autumn $(\mathrm{p}<0.05)$.

Appendicularians presented higher abundances in summer and spring $\left(2,516\right.$ and 2,485 ind. $\mathrm{m}^{-3}$, 
respectively) and the lowest value in autumn (527 ind. $\mathrm{m}^{-3}$ ) (Table 2). Significant differences were recorded among seasons $\left(\mathrm{H}_{(3, \mathrm{~N}=81)}=14.02\right.$; $\mathrm{p}=.0029)$, with autumn differing from summer and spring $(\mathrm{p}<0.05)$.

Chaetognaths exhibited their highest abundance in summer (75 ind. $\mathrm{m}^{-3}$ ) and the lowest one in spring (19 ind. $\mathrm{m}^{-3}$ ) (Table 2). Significant differences among seasons were observed $\left(\mathrm{H}_{(3, \mathrm{~N}=80)}=10.79 ; \mathrm{p}=0.0129\right)$ but only winter and spring distinguished significantly $(\mathrm{p}<0.05)$ between them.

Grouping of taxa and their correlation with physical variables

Factors 1, 2, and 3 of the PCA explained $56.67 \%$ of the variance (Figure 4). In the space configured by factors 1 and 2, a group of six taxa (OIT, PACL, OITN, PACLN, ENO, and APP) evidenced negative correlations with factor 1 (Table 3; Figure 4) and clearly separated from CAL and PAV. These six taxa occurred all year round with higher abundances during spring and summer. In several cases, significant positive correlations among them and physical variables, especially MT and $\varphi$, were observed (Table 4).

On the contrary, CAL was strongly associated with negative values of factor 2 (Table 3; Figure 4). CAL occurred throughout the year with the highest abundance in winter, showing a negative correlation with PAV and a positive one with CHA. As regards physical variables, CAL was negatively correlated with MT and $\varphi$ (Table 4).

PAV was strongly and positively related to factor 2 (Table 3 ). This species was partially present throughout the year, with maximum abundance in summer and showing a positive correlation with PACL and a negative one with OITN and CAL (Table 4).

CHA was positively associated to factor 3 (Figure 4). This taxon presented the lowest abundances in spring, a negative correlation with both OIT and $\varphi(\mathrm{p}<0.05)$, and a strong positive correlation with CAL $(\mathrm{p}<0.001)$ (Table 4).
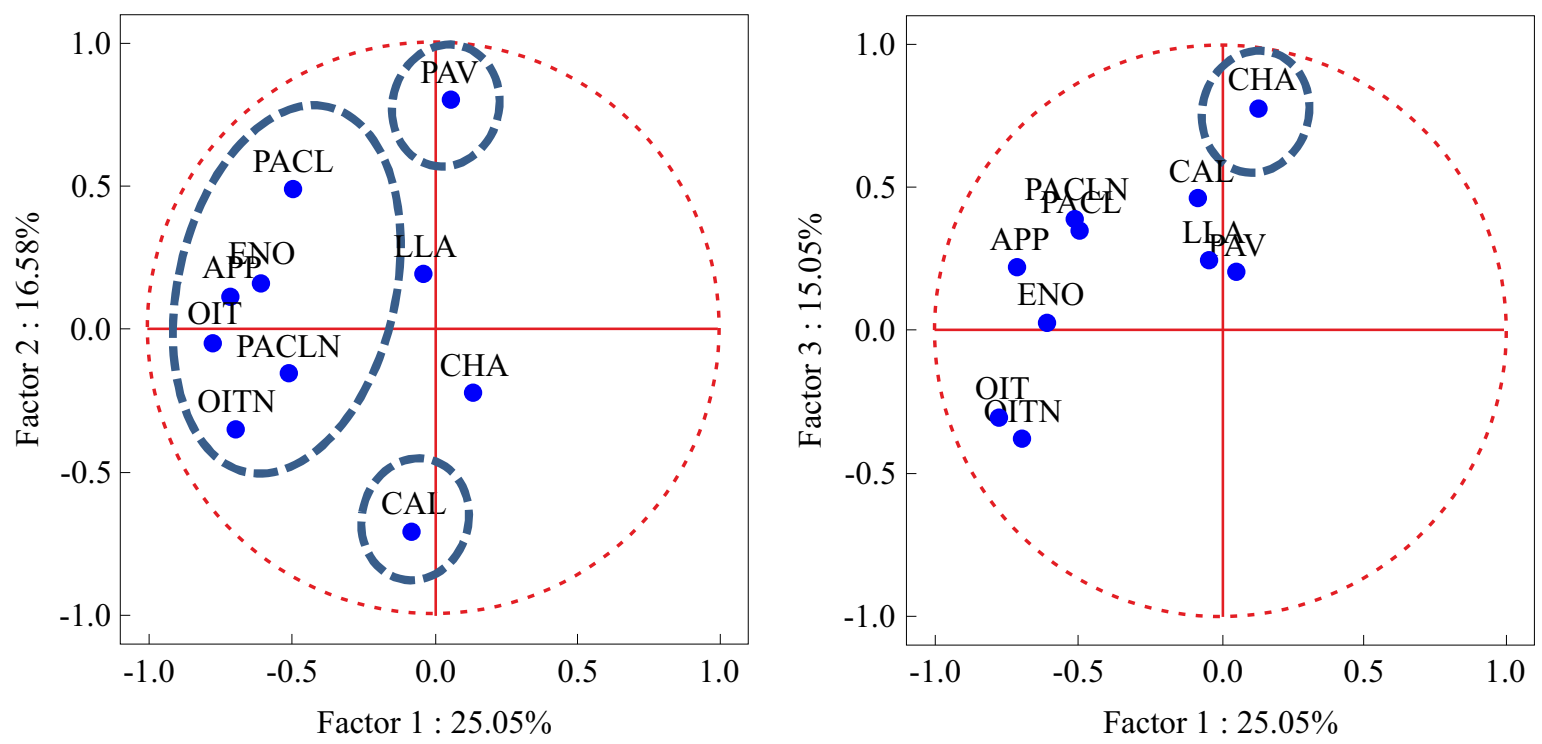

Figure 4. Principal Component Analysis (PCA) results. Projection of variables on the factor planes 1 x 2 (on the left) and 1 x 3 (on the right). Oithonidae (OIT), Paracalanidae-Clausocalanidae (PACL), Evdne nordmanni (ENO), Penilia avirostris (PAV), nauplii of Oithonidae (OITN), nauplii of Paracalanidae-Clausocalanidae (PACLN), Appendicularians (APP), Calanidae (CAL), Chaetognaths (CHA), Lamellibranch larvae (LLA). Blue dashed ellipses indicate grouping of taxa (see text). 
Table 3. Principal Component Analysis (PCA) results. Factor coordinates of the variables. Variables that contributed the most to each factor are indicated in bold.

\begin{tabular}{lccc}
\hline Variable & Factor 1 & Factor 2 & Factor 3 \\
\hline OIT & $\mathbf{- 0 . 7 8}$ & -0.05 & -0.30 \\
OITN & $\mathbf{- 0 . 7 0}$ & -0.35 & -0.38 \\
PACL & $\mathbf{- 0 . 5 0}$ & 0.49 & 0.35 \\
PACLN & $\mathbf{- 0 . 5 1}$ & -0.15 & 0.40 \\
ENO & $\mathbf{- 0 . 6 1}$ & 0.16 & 0.03 \\
APP & $\mathbf{- 0 . 7 1}$ & 0.12 & 0.23 \\
PAV & 0.05 & $\mathbf{0 . 8 0}$ & 0.21 \\
CHA & 0.13 & -0.22 & $\mathbf{0 . 7 8}$ \\
CAL & -0.08 & $\mathbf{- 0 . 7 1}$ & 0.47 \\
LLA & -0.04 & 0.19 & 0.25 \\
\hline
\end{tabular}

\section{Long-term interannual variability}

Among all the zooplankton categories analyzed, OIT and OITN showed increasing patterns of variation, but trends were not statistically significant (Figure $5 \mathrm{~A}$ and $5 \mathrm{~B}$ ). By contrast, CAL, LLA and CHA exhibited decreasing anomalies (Figures $6 \mathrm{~A}, 6 \mathrm{~B}$ and $9 \mathrm{~B}$ ).

Other taxa such as PACL, PACLN, ENO, PAV and APP displayed neutral trends (Figures 7 A, 7 B, 8 A, 8 B and 9 A). No significant relationships among anomalies of biological and physical variables were observed.

\section{Long-term seasonal variability}

Non-significant annual trends were observed in the analyzed taxa of this time series. However, at a seasonal scale, some significant tendencies were registered. CAL and LLA exhibited decreasing trends in winter $(\mathrm{p}=0.05$ and $\mathrm{p}=0.03$, respectively). Also, a negative tendency was observed for chaetognaths in summer $(\mathrm{p}=0.03)$ and a positive one for appendicularians in spring $(\mathrm{p}=0.02)$. These anomalies had no significant correlation with those of the physical parameters.

\section{DISCUSSION}

\section{Hydrography}

In terms of the seasonal cycle, temperature at the EPEA station behaves like a region influenced by the deep water of Península Valdés (Luz Clara et al. 2019). Minimum temperatures occurred in July-September (with a peak in August) and maximum values corresponded to January-March (peaking in February), in response to the annual radiative cycle effect, as observed in other studies in the South Atlantic Ocean (e.g. Podestá et al. 1991; Lentini et al. 2000; Martínez-Avellaneda 2005; Luz Clara et al. 2019).

\section{Zooplankton}

\section{Composition and seasonal abundance}

PCA analysis grouped zooplankton taxa with similar environmental affinity. The resulting pattern was comparable in composition with that found by Viñas et al. (2013) in their annual 20002001 study of zooplankton at the EPEA station. One group, including species with more affinity 
Table 4. Significant linear correlations among biological variables $(\log x+1)$ and between these ones and physical variables.

\begin{tabular}{|c|c|c|c|c|}
\hline Biological variable 1 & Biological variable 2 & $\mathrm{r}$ & $p$ & $\mathrm{~N}$ \\
\hline OIT & OITN & 0.665 & 0.000 & 80 \\
\hline OIT & PACL & 0.362 & 0.001 & 80 \\
\hline OIT & PACLN & 0.232 & 0.038 & 80 \\
\hline OIT & APP & 0.321 & 0.004 & 80 \\
\hline OIT & ENO & 0.222 & 0.048 & 80 \\
\hline OIT & CHA & -0.265 & 0.017 & 80 \\
\hline PACL & PACLN & 0.297 & 0.007 & 80 \\
\hline PACL & APP & 0.346 & 0.002 & 80 \\
\hline PACL & PAV & 0.348 & 0.002 & 80 \\
\hline CAL & PAV & -0.328 & 0.003 & 80 \\
\hline CAL & CHA & 0.382 & 0.000 & 80 \\
\hline APP & ENO & 0.518 & 0.000 & 80 \\
\hline APP & OITN & 0.310 & 0.005 & 80 \\
\hline APP & PACLN & 0.251 & 0.025 & 80 \\
\hline ENO & OITN & 0.284 & 0.011 & 80 \\
\hline PAV & OITN & -0.221 & 0.048 & 80 \\
\hline Biological variable & Physical variable & $\mathrm{r}$ & $p$ & $\mathrm{~N}$ \\
\hline PACL & MT & 0.317 & 0.002 & 93 \\
\hline CAL & MT & -0.270 & 0.009 & 93 \\
\hline OIT & $\varphi$ & 0.238 & 0.021 & 93 \\
\hline PACL & $\varphi$ & 0.213 & 0.040 & 93 \\
\hline CAL & $\varphi$ & -0.294 & 0.004 & 93 \\
\hline CHA & $\varphi$ & -0.222 & 0.033 & 93 \\
\hline
\end{tabular}

for warm-temperate waters of spring and summer such as the small copepods Oithonidae and Paracalanidae-Clausocalanidae, the cladoceran $E$. nordmanni and appendicularians, separated from the large herbivore $C$. carinatus (Calanidae), which showed more affinity to colder winter waters (Cepeda et al. 2018 and references therein) and from the cladoceran $P$. avirostris, with more affinity for warmer waters of summer (Viñas et al. 2007). Chaetognaths presented their highest values in summer followed by lower and similar values in autumn and winter. A comparable pattern of seasonal abundance was found by
Daponte et al. (2004) in their study of an annual cycle of Sagitta friderici, the main chaetognath species of the EPEA station.

Copepod species smaller than $1 \mathrm{~mm}$ total length numerically dominated the zooplankton community throughout the year during the study period. At the EPEA station, this fraction exceeds other copepods not only in terms of abundance but also in biomass (Viñas et al. 2013). Small copepods are very abundant in temperate and tropical coastal regions (Mazzocchi and Ribera d'Alcalá 1995; Hopcroft et al. 2001; Satapoomin et al. 2004; Turner 2004; Atienza et al. 2006; Zer- 

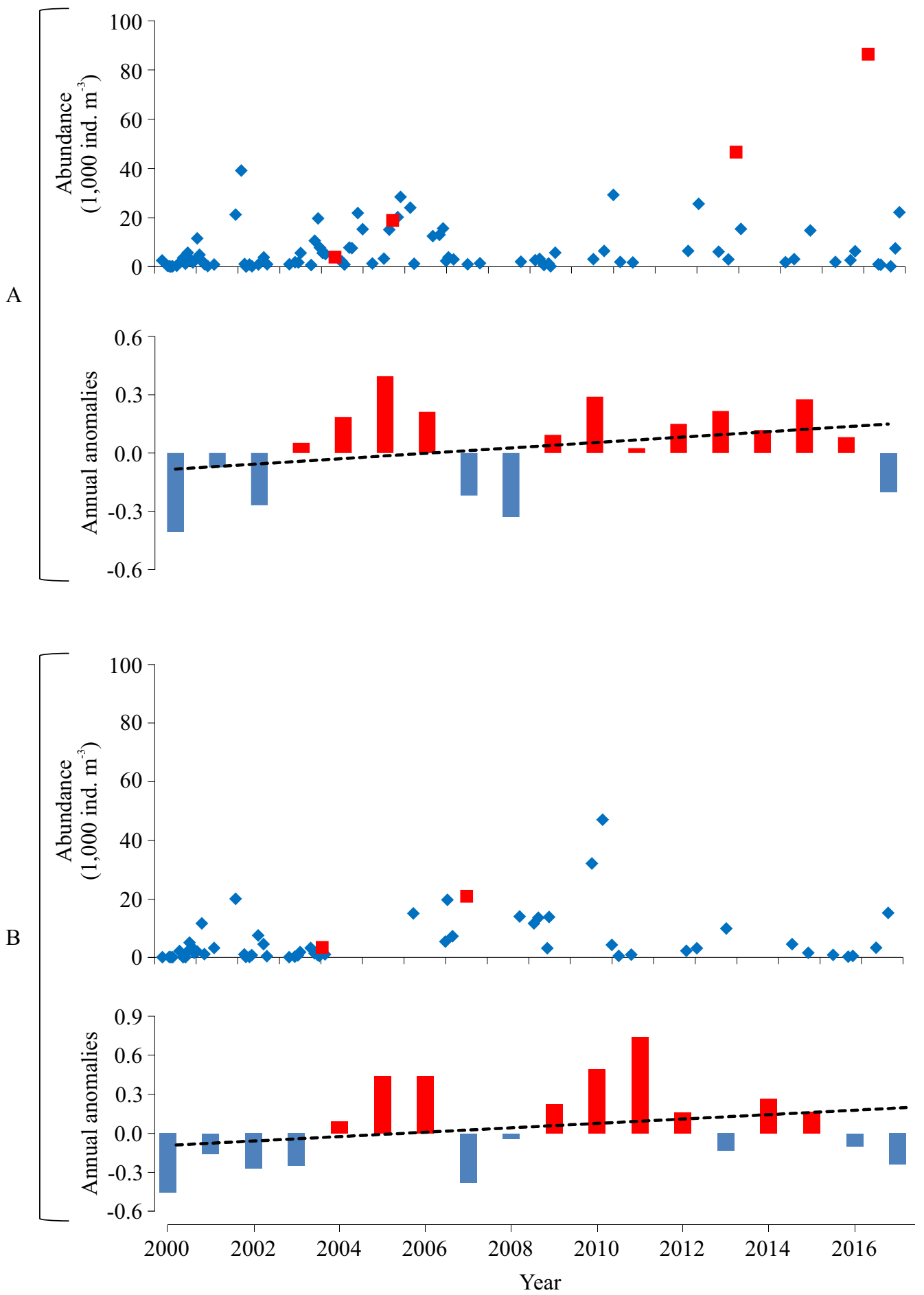

Figure 5. Interannual variation of abundance and annual anomalies of OIT (A) and OITN (B) during the period 2000-2017 at the EPEA station. Red squares: outliers. Dashed line: ns. trend. 

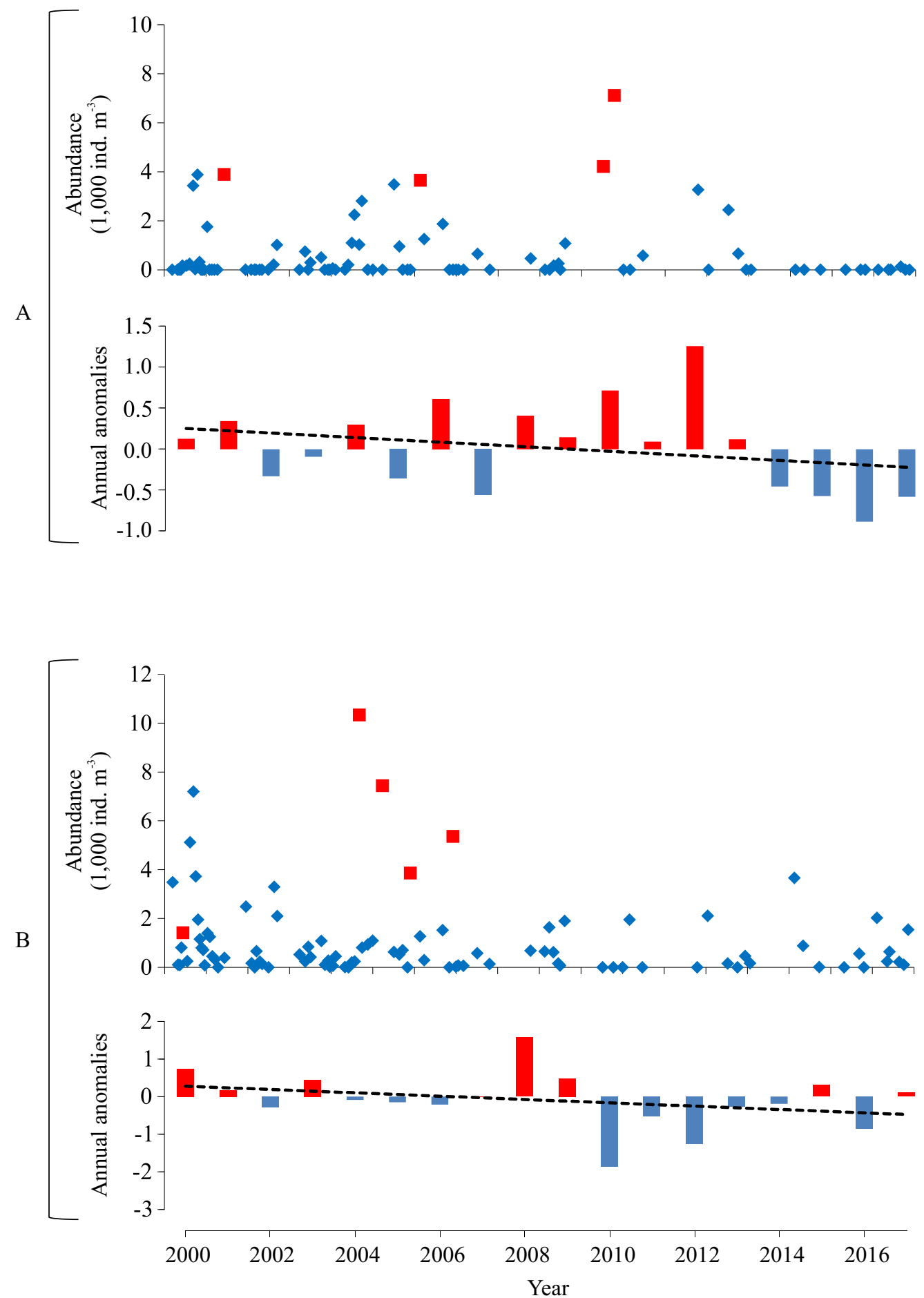

Figure 6. Interannual variation of abundance and annual anomalies of CAL (A) and LLA (B) during the period 2000-2017 at the EPEA station. Red squares: outliers. Dashed line: ns. trend. 

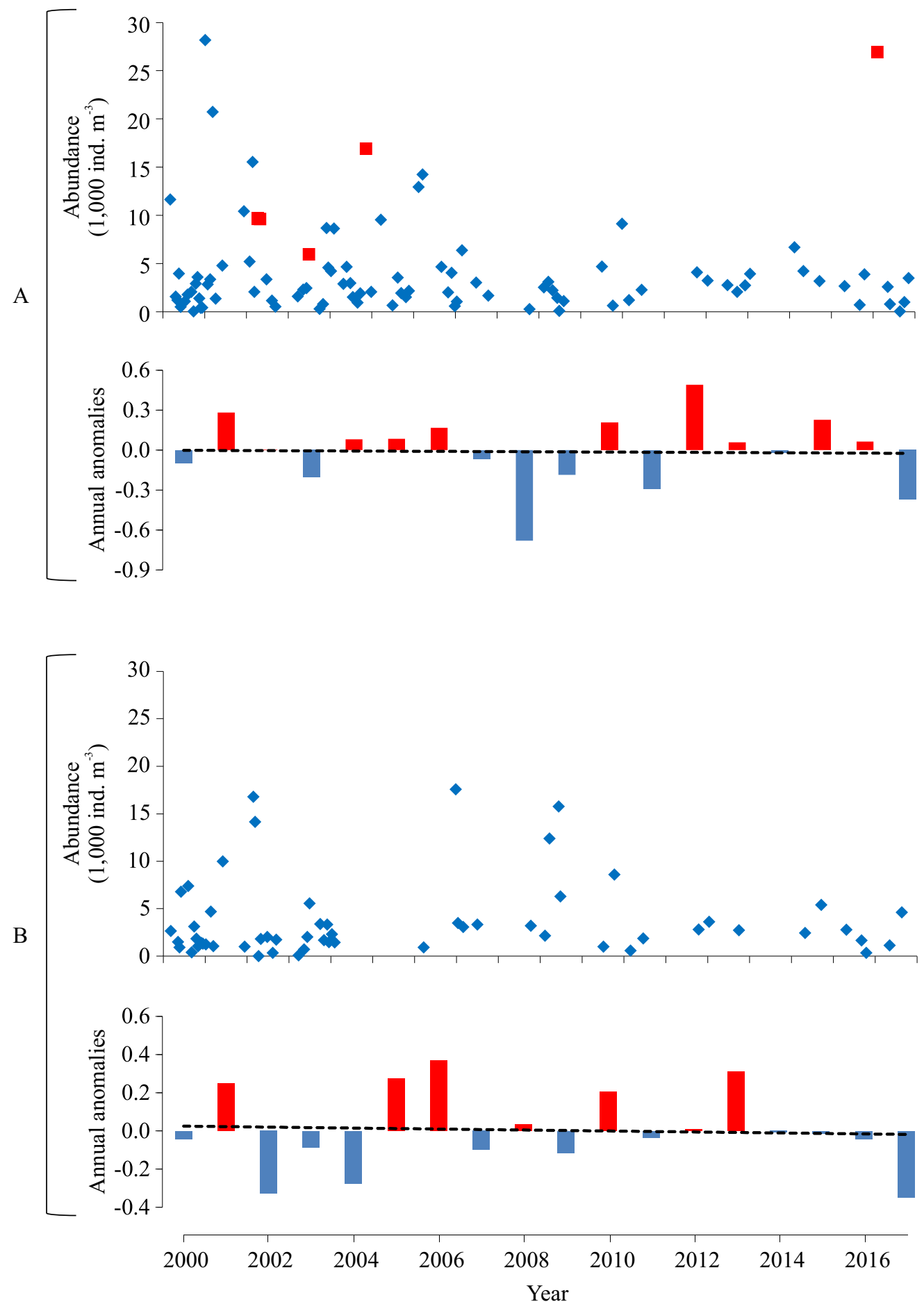

Figure 7. Interannual variation of abundance and annual anomalies of (A) PACL and (B) PACLN during the period 2000-2017 at the EPEA station. Red squares: outliers. Dashed line: ns. trend. 


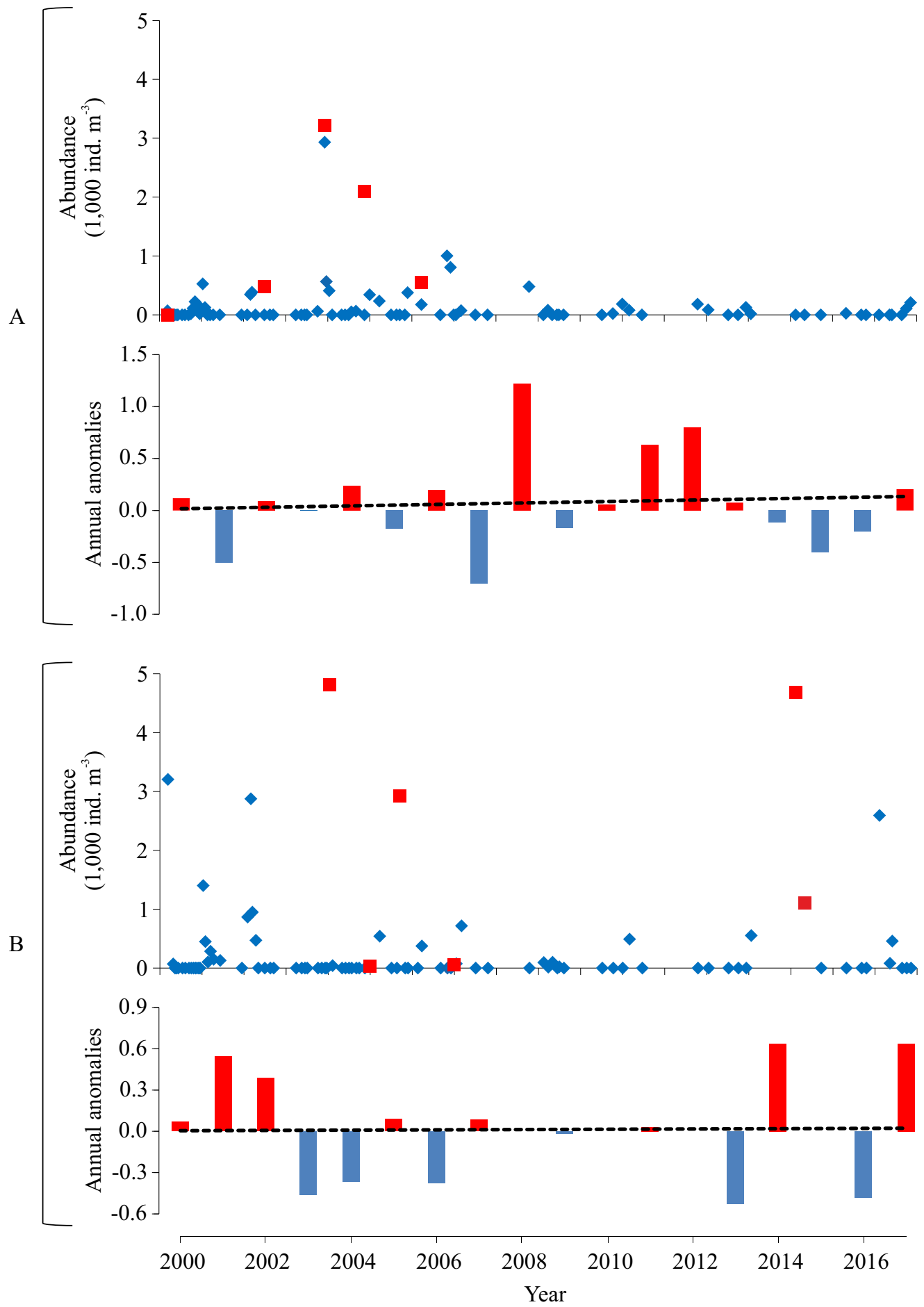

Figure 8. Interannual variation of abundance and annual anomalies of ENO (A) and PAV (B) during the period 2000-2017 at the EPEA station. Red squares: outliers. Dashed line: ns. trend. 

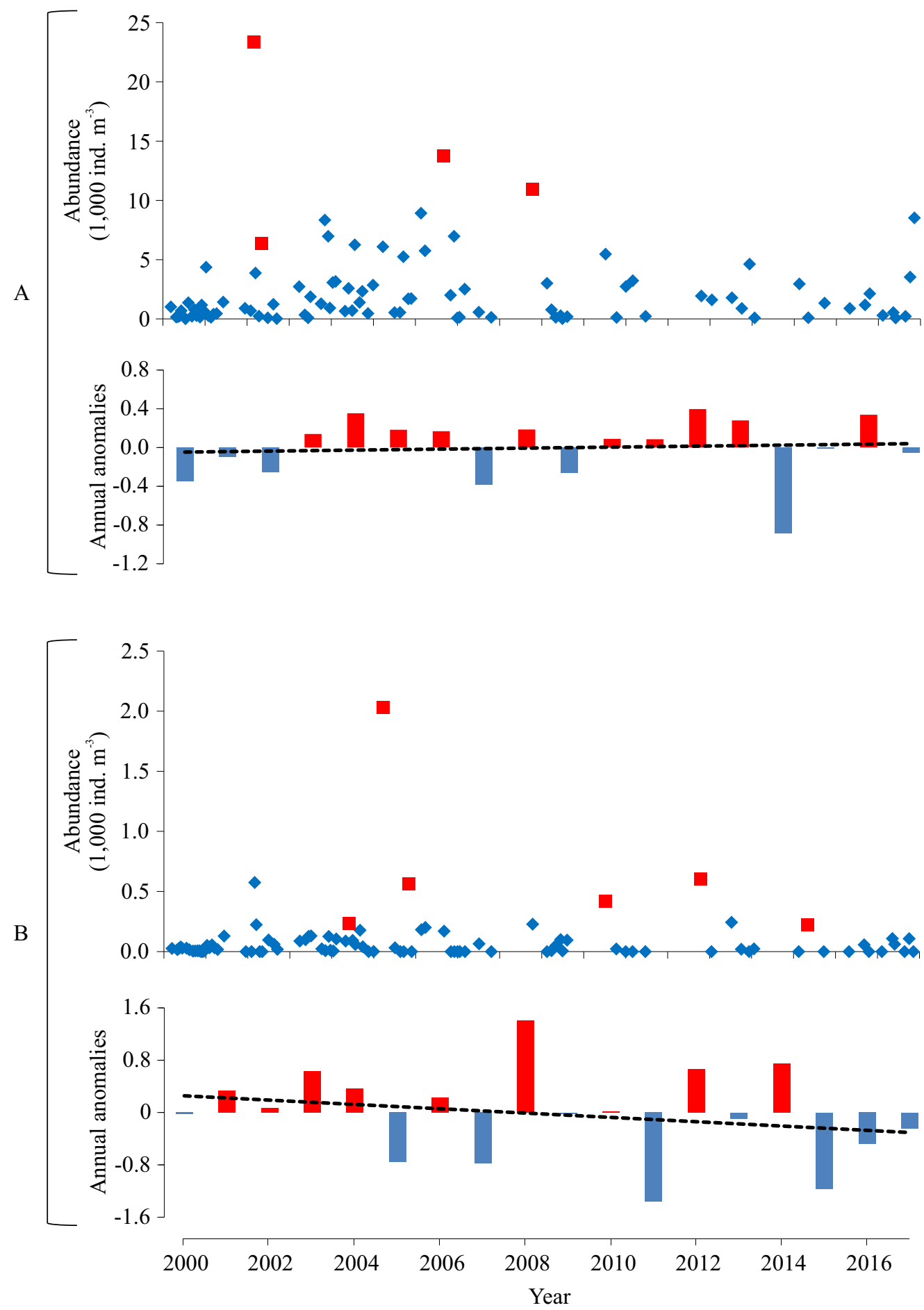

Figure 9. Interannual variation of abundance and annual anomalies of APP (A) and CHA (B) during the period 2000-2017 at the EPEA station. Red squares: outliers. Dashed line: ns. trend. 
voudaki et al. 2007) including the Argentine shelf where they distribute in a large latitudinal range (Ramírez, 1981; Cepeda et al. 2018). Moreover, it was shown that small copepods and their early developmental stages dominate all marine communities (Hopcroft et al. 2001).

In the taxonomic analysis, a great percentage of adults ( $c a .80 \%)$ of Oithonidae were identified as belonging to $O$. nana (not shown). Accordingly, the present study assumes that most of the copepodite and nauplii stages of Oithonidae also corresponded to this species. In coincidence with the present findings, a high abundance of $O$. nana in all seasons has been typically observed at the EPEA station (Temperoni et al. 2011; Viñas et al. 2013). The great tolerance of this species to seasonal variation of temperature might explain its ample distribution in temperate and tropical coastal waters all around the world, i.e. the Mediterranean Sea (Jamet et al. 2001), Southampton Water (Williams and Muxagata 2006), and the Argentine shelf (Cepeda et al. 2015, 2018).

The notorious numerical dominance of Oithonidae (mainly O. nana) all through the year is probably related to its ability to consume a wide size range of food particles including microphytoplankton, microbial heterotrophic components, and copepod nauplii (Paffenhöfer 1993; Turner 2004; Atienza et al. 2006; Madsen et al. 2008; Böttjer et al. 2010). An additional advantage could be the reproductive modality of this species. The egg-carrier trait might be a good strategy to prevent eggs predation, thus assuring higher survival rates and consequently more abundant populations (Kiørboe et al. 2015).

On a seasonal basis, the abundance of $O$. nana started increasing in winter and attained its highest abundance in spring. In accordance, microphytoplankton showed a similar pattern (Viñas et al. 2013; Negri et al. in preparation). During this period, adequate temperature range and food availability have probably stimulated $O$. nana females to reproduce intensively producing the highest peak of nauplii of the year. O. nana as well as Paracalanidae, very abundant in summer, might have taken advantage of high densities of microbial components associated to the abundant picophytoplankton fraction recorded during this season. In fact, this fraction had an outstanding contribution from the end of spring up to early autumn (Ruiz et al. 2020; Negri et al. in preparation) during present period. Silva et al. (2009) reported that this fraction can reach 50$90 \%$ of the total Chl- $a$ at the EPEA station during summer.

It is worth mentioning that small copepods (such as all stages of $O$. nana and ParacalanidaeClausocalanidae) are not able to graze efficiently upon nano and picophytoplankton components. In fact, these fractions are consumed by nanoand micro-heterotrophs which are predated by protozooplankton, especially ciliates, and the latter are the main prey for small copepods. In particular, they have a greater influence on the efficiency of the trophic food webs than larger species, coupling between the primary producers, the protozooplankton, and the higher trophic levels (Zervoudaki et al. 2007).

Microbial filter-feeders $P$. avirostris and appendicularians displayed also their maximum abundance in summer. As mentioned above, this period is characterized by a strongly stratified water column with phytoplankton biomass mostly represented by nano- and picophytoplankton fractions (Silva et al. 2009; Viñas et al. 2013). Penilia avirostris grazes mostly on small flagellates, dinoflagellates and diatoms (Atienza et al. 2006), whereas appendicularians are major picoand nanoplankton feeders (Flood et al. 1992; Tönnesson et al. 2005). The dominance of microbial filter-feeding such as cladocerans and larvaceans in warmer seasons is a common feature in coastal waters of the Mediterranean (Ribera d'Alcalá et al. 2004) and the Aegean and Black Seas (Siokou-Frangou et al. 2004) as well as in the Northeast Atlantic (Rodriguez et al. 2000).

In summer, chaetognaths, mostly represented by $S$. friderici (Daponte et al. 2004) also exhibit- 
ed their highest abundance. It is well known that older chaetognaths prey upon appendicularians (Purcell et al. 2004) and small copepodite stages (Sato et al. 2011a), which are very abundant during this season.

Present series recorded the highest abundance of the herbivorous calanoid $C$. carinatus in cold waters of winter and spring. The high nutrient input typical of the mixing during the winter period and the starting of water column stratification in spring favor the development of the main phytoplankton bloom of the year represented mainly by the microphytoplankton fraction (Carreto et al. 1998; Negri and Silva 2003; Viñas et al. 2013). Diatoms and dinoflagellates are the main food of C. carinatus (Cepeda et al. 2018 and references therein).

\section{Long term annual and seasonal variability}

During the study period, a positive trend of interannual anomalies was observed in the mean temperature of the water column, but it was nonsignificant. However, bottom and surface temperature analysis of a longer series (19 years) in the EPEA showed a significant positive trend, as also occurred in an extended satellite-sea surface-temperature-series (Luz Clara et al. in preparation).

In support of our initial hypothesis, the abundance of Family Oithonidae (more abundant small copepods of the EPEA zooplankton community) increased during the 18 years of observation. This is clearly perceived when comparing the abundance of this species at the beginning of the series (period 2000-2001; Viñas et al. 2013) with results of the entire series between 2000 and 2017. In summer 2000, OIT abundance (adults + copepodites) was $4,428 \pm 5,816$ ind. $\mathrm{m}^{-3}$ on average, whereas in the total series it was 7,159 \pm 10,289 ind. $\mathrm{m}^{-3}$. In spring 2000 its abundance attained only $2,293 \pm 1,497$ ind. $\mathrm{m}^{-3}$, five times less than in the present study (mean 11,793 \pm 9,200 ind. $\mathrm{m}^{-3}$ ). However, non-significant correlation was found between interannual anomalies of the abundance of these species and those of the temperature during the sampling period. Duration of time-series was probably no long enough to detect such relationships in both Oithonidae and other categories of metazooplankton.

It should be noted that in coincidence with the positive trend observed in Oithonidae, concentrations of $C h l_{\text {total }}$ and $C h l_{<5}$ showed a significant increasing trend during the present series (Silva 2011; Ruiz et al. 2020; Negri et al. in preparation). Percentage of $\mathrm{Chl}_{<5}$ displayed a significant positive trend coincident with a significant positive tendency of pico and nanophytoplankton fractions (Negri et al. in preparation). Increasing food availability from a rich microbial food web could have favored the development of Oithonidae populations in the long-term, as it was observed in summer, on a seasonal scale.

As previously mentioned, small copepod species are the major contributor to the total copepod community abundance at the EPEA station, especially during the warmest period of the year. This is probably related to the positive and direct influence of the increasing temperature on their reproductive cycle (Uye and Shibuno 1992; Pittois et al. 2009) as well as the indirect and favorable influence of this parameter increasing the abundance of the smaller phytoplankton fraction (Negri et al. in preparation).

But not all the zooplankton species of the EPEA community seemed to be favored by the temperature increase and its possible influence upon the phytoplankton structure and phenology, among other factors. For example, a significant decreasing trend was observed in winter on the abundance of herbivorous like lamellibranch larvae and the calanoid C. carinatus during 20002017 series. The highest peak of abundance of lamellibranch larvae was recorded in August (winter). Although no information on the species composition of these larvae was available in the present zooplankton series, they probably belonged to Mytilus platensis, which beds are distributed in the study area (Bremec and Lasta 1998). A marked synchrony in the emission of 
gametes with peaks of reproductive activity during September and October has been reported for M. platensis in the study area (Penchaszadeh 1980). In the present work, maximum emission of gametes corresponded to August, one month earlier than usual. One explanation for this observed decreasing anomaly could be the temperature rise on the sea surface throughout the time-series studied. In such conditions, adults of M. platensis, stimulated by higher temperature ranges, could have had their spawning timing earlier, which could produce a mismatch between the recently hatched larvae and the adequate phytoplankton cells that bloom later in the season. Similarly, the decreasing tendency observed in $C$. carinatus was probably due to the same causes. In both cases, fitness consequences tend to be negative when the organism is at the wrong seasonal window. In other words, as the species completes its life span within a single year, the fact of missing the best window to grow during that year prevents them from getting another chance the following year (Mackas et al. 2012). Future results of ongoing analysis of phytoplankton diversity and long-term variability of the present series (Negri et al. in preparation) would give some insight to test this hypothesis.

Perturbations to average seasonal cycles of environmental conditions, and the ability (or inability) of biota to track these variations are very important drivers of interannual variability in growth, survival, and population size (Mackas et al. 2012), as it was observed in the present work.

Small copepods represent a main food source for local fish, especially during larval stages (Viñas and Ramírez 1996; Sato et al. 2011b). If the observed increasing tendency of these species (mainly $O$. nana and members of Paracalanidae-Clausocalanidae) remains in the long term, this would expand the availability of food for fish larvae, thus favoring their growth and survival. In the study area, Engraulis anchoita larvae are dominant during a great part of the year (Sánchez and Ciechomski 1995). With acoustic biomass fluctuating between one and five million tons in the period 1993-2008 (Madirolas et al 2013), this species has a superlative ecological importance because of its central role in pelagic food webs in the Argentine shelf (Leonarduzzi et al. 2010 and references therein). A recent study analyzing the same time-series denoted that density and nutritional condition of anchovy larval were higher in spring and autumn, but lower in winter (Leonarduzzi et al. 2021). Interestingly, the present work shows that higher concentrations of small copepods (all stages together) were observed in spring and summer whereas lower values corresponded to autumn. Many factors must should be considered to understand larval-zooplankton relationships: real concentration of food in the larval habitat (a mean concentration in the water column is not the best approach), seasonal predators abundance (non-considered in present work) and concentration of other zooplanktonic food items (i.e. protozooplankton), among others.

Time series provide the oceanographic community with the long, high-quality data necessary to characterize the functioning of the ocean (Henson 2014) and help to unravel natural and humaninduced changes in marine ecosystems (Reid and Valdés 2011). Consequently, these time-series sampling sites represent a phenomenal heritage legacy, and intergovernmental bodies such as ICES, the European Marine Board, or IOCUNESCO strongly recommend their continuity and the establishment of new time-series based on previous findings (Valdés and Lomas 2017).

\section{CONCLUSIONS}

This work covers a time-series of 18 years in which the variability of main metazooplankton taxa of the EPEA station was studied for the first time. Results indicated that small copepods dom- 
inate the metazooplankton at this station. The most abundant family, Oithonidae, showed an interannual increasing trend during the study period, whereas lamellibranch larvae and other cryophilic taxa exhibited a decreasing trend. Physical parameters (MT, MS and $\varphi$ ) did not show significant interannual trends. However, temperature exhibited a strong increasing tendency. No clear relationships were found between both long-term interannual and seasonal anomalies of taxa and those of the physical parameters, probably because of the short period analyzed. The increasing of Oithonidae abundance could be due both to the direct effect of the temperature rise on their reproductive rates and the positive influence of this parameter on the concentration of small phytoplankton fractions, an important food item for these copepods. Opposite, for other cryophilic taxa such as Calanidae and lamellibranch larvae with decreasing abundances, the increase of temperature could have had a negative effect, although the mechanisms involved are less clear. More observations are necessary to confirm these hypotheses.

\section{ACKNOWLEDGMENTS}

INIDEP provided financial support for samples collection. We thank all the colleagues of the DIPLAMCC project who collaborated in onboard activities during the cruises. We are grateful to the captains and crews of all the vessels who took part in EPEA cruises for their shipboard assistance. Part of the equipment used in this work was acquired through grants from the Agencia Nacional de Promoción Científica y Tecnológica (PICT 15227/03), Universidad Nacional de Mar del Plata EXA717/14 and EXA843/17 to MDV. Our acknowledgment to anonymous reviewers who provided very constructive comments on the earlier version of the manuscript. This is INIDEP contribution no 2246.

\section{REFERENCES}

Atienza D, Calbet A, Saiz E, Alcaraz M, TrePAT I. 2006. Trophic impact, metabolism, and biogeochemical role of the marine cladoceran Penilia avirostris and the co-dominant copepod Oithona nana in NW Mediterranean coastal waters. Mar Biol. 50: 221-235.

BeAugrand G, Kirby RR. 2018. How do marine pelagic species respond to climate change? Theories and observations. Ann Review Mar Sci. 10: 169-197.

Behrenfeld MJ, O'Malley RT, Siegel DA, McClain CR, Sarmiento JL, Feldman GC, Milligan AJ, Falkowski PG, Letelier RM, Boss ES. 2006. Climate-driven trends in contemporary ocean productivity. Nature. 444: 752-755.

Böttjer D, Morales CE, Bathmann U. 2010. Trophic role of small cyclopoid copepod nauplii in the microbial food web: a case study in the coastal upwelling system off central Chile. Mar Biol. 157: 689-705.

BREMEC CM, LASTA M. 1998. Mapeo sinóptico del macrobentos asociado a la dieta en fondos de alimentación de la corvina rubia (Micropogonias furnieri) en el área de El Rincón. Noviembre, 1994. INIDEP Inf Téc. 21: 117132.

Capitanio Fl, Curelovich J, Tresguerres M, Negri RM, Viñas MD, Esnal G. 2008. Seasonal cycle of appendicularians at a coastal station $\left(38^{\circ} 28^{\prime} \mathrm{S}, 57^{\circ} 41^{\prime} \mathrm{W}\right)$ of the SW Atlantic Ocean. B Mar Sci. 82:171-184.

Carreto Ji, Akselman R, Montoya NG, Negri RM, Benavídes HR, Carignan MO, Cucchi Colleoni AD. 1998. Alexandrium tamarense Bloom dynamics and Mytilus edulis toxicity in the coastal waters off Mar del Plata (Argentina). In: Reguera B, Blanco J, Fernández MI, WyATT T, editors. Harmful microalgae. Santiago de Compostela: Xunta de Galicia and 
IOC-UNESCO: 135-138.

Cepeda G. 2013. Sistemática molecular, distribución y dinámica poblacional de las especies de Oithona (Copepoda, Cyclopoida) en diversos sectores costeros del Mar Argentino [PhD thesis]. Mar del Plata: Facultad de Ciencias Exactas y Naturales, Universidad Nacional de Mar del Plata. 193 p.

Cepeda GD, Di Mauro RP, Hozbor MC, Cucchi Colleoni BD, Hernández D, Viñas MD. 2015. Spatial variation in life-history traits of Oithona spp. in a shallow temperate estuarine system (Río de la Plata, south-west Atlantic) during spring. Mar Freshwater Res. 66: 795804.

Cepeda G, Temperoni B, Sabatini M, Viñas MD, Derisio C, Santos B, Antacli J, PadoVANI L. 2018. Zooplankton communities of the Argentine continental shelf (SW Atlantic, $c a$. $34^{\circ}-55^{\circ} \mathrm{S}$ ) an Overview. In: HOFFMEYER M, Sabatini M, Brandini F, Calliari D, SantiNELLI N, editors. Plankton ecology of the Southwestern Atlantic from the subtropical to the subantarctic realm. Springer. p. 171-200.

Daponte MC, Capitanio FL, Nahabedian DE, ViÑas MD, Negri RM. 2004. Sagitta friderici Ritter-Zahony (Chaetognatha) from South Atlantic waters: abundance, population structure, and life cycle. ICES J Mar Sci. 61: 680686.

Di Mauro R, Capitanio F, Viñas MD. 2009. Capture efficiency for small dominant mesozooplankters (Copepoda, Appendicularia) off Buenos Aires Province $\left(34^{\circ} \mathrm{S}-41^{\circ} \mathrm{S}\right)$, Argentine Sea, using two plankton mesh sizes. Braz J Oceanogr. 57: 205-214.

Diosalvi N. 2006. Estudio del ciclo anual del mesozooplancton en una estación permanente ubicada en aguas costeras bonaerenses [tesis de grado]. Mar del Plata: Facultad de Ciencias Exactas y Naturales, Universidad Nacional de Mar del Plata. 48 p.

EDWARDS M, RichARDSON AJ. 2004. The impact of climate change on the phenology of the plankton community and trophic mismatch. Nature. 430: 881-884.

Edwards M, Beaugrand G, Hays GC, Koslow, JA, Richardson AJ. 2010. Multidecadal oceanic ecological datasets and their application in marine policy and management. Trends Ecol Evol. 25: 602-610.

Flood PR, Deibel D, Morris CC. 1992. Filtration of colloidal melanin from sea-water by planktonic tunicates. Nature. 355: 630-632.

HAYS GC, RichaRdSON AJ, RoBINSON C. 2005. Climate change and plankton. Trends Ecol Evol. 20: 337-344.

HENSON SA. 2014. Slow science: the value of long ocean biogeochemistry records. Philos Trans R Soc A. 372. doi:10.1098/rsta.2013. 0334

Hopcroft RR, Roff JC, Chavez FP. 2001. Size paradigms in copepod communities: a reexamination. Hydrobiologia. 453: 133-141.

[IPCC] Grupo InTERGUBERNAMENTAL DE EXPERtos sobre el CAmbio Climático. 2019. El océano y la criosfera en un clima cambiante. Informe especial del Grupo Intergubernamental de Expertos sobre el Cambio Climático. Resumen para responsables de políticas. In: PÖrtner HO, Roberts DC, MASSON-Delmotte V, Zhai P, Tignor M, Poloczanska E, Mintenbeck K, Nicolai M, Okem A, PetZOLD J, RAMA B, WEYER NM, editors. Geneva: IPCC. $38 \mathrm{p}$.

Jamet JL, Bogé G, Richard S, Geneys C, JAMET D. 2001. The zooplankton community in bays of Toulon area (northwest Mediterranean Sea, France). Hydrobiologia. 457: 155-165.

Kiørboe T, Ceballos S, Høgsbro Thygesen U. 2015. Interrelations between senescence, lifehistory traits, and behavior in planktonic copepods. Ecology. 96 (8): 2225-2235.

Lentini Cad, CAmpos EJD, Podestá GG. 2000. The annual cycle of satellite derived sea surface temperature on the western South Atlantic shelf. Rev Bras Oceanogr. 48 (2): 93105. 
Leonarduzzi E, Brown DR, SÁnchez R. 2010. Seasonal variations in the growth of anchovy larvae (Engraulis anchoita) on the Argentine coastal shelf. Sci Mar. 74: 267-274.

Leonarduzzi E, Do Souto M, Diaz MV. 2021. Early stages of anchovy: abundance, variability and larval condition at the fixed coastal station EPEA between 2000-2017. Mar Fish Sci. 34 (2): 123-142.

Li WKW, Harrison WG. 2008. Propagation of an atmospheric climate signal to phytoplankton in a small marine basin. Limnol Oceanogr. 53: 1734-1745.

Luz Clara M, Simionato CG, Jaureguizar AJ. 2019. Annual variability of sea surface temperature in the northern Argentinean continental shelf. Geoacta. 43.

Mackas DL, Greve W, Edwards M, Chiba S, TAdokoro K, Eloire D, MAZzocchi MG, Batten S, Richardson A, Johnson C, et al. 2012. Changing zooplankton seasonality in a changing ocean: comparing time series of zooplankton phenology. Progr Oceanogr. 97-100: 31-62.

Mackas D, Thomson RE, Galbraith M. 2001. Covariation of zooplankton community changes and oceanographic conditions on the British Columbia continental margin, 19951998. Can J Fish Aquat Sci. 58: 1-18.

Madirolas A, Cabreira A, Hansen JE. 2013. Revisión y síntesis de las estimaciones acústicas de abundancia de anchoíta (Engraulis anchoita) efectuadas entre 1993 y 2008. Rev Invest Desarr Pesq. 23: 35-48.

Madsen SD, Nielsen TG, Hansen BW. 2008. Annual population development and production by small copepods in Disko Bay, western Greenland. Mar Biol. 155: 63-77.

MartíneZ-Avellaneda N. 2005. Ciclo anual y variabilidad de baja frecuencia de la temperatura superficial del mar en el Océano Atlántico Sudoccidental [tesis de licenciatura]. Buenos Aires: Facultad de Ciencias Exactas y Naturales, Universidad de Buenos Aires. 133 p.
Mauchline J. 1998. The biology of calanoid copepods. Adv Mar Biol. 33. 710 p.

Mazzocchi MG, RiBERA D'Alcala M. 1995. Recurrent patterns in zooplankton structure and succession in a variable coastal environment. ICES J Mar Sci. 52: 679-691.

Moran XAG, LóPez-Urruria A, Calvo-Diaz A, LI WKW. 2010. Increasing importance of small phytoplankton in a warmer ocean. Global Change Biol. 16: 1137-1144.

Muller Karger Fe, Piola A, Verheye hM, O'Brien TD, Lorenzoni L. 2017. South Atlantic Ocean. In: O'BrIEN TD, LORENZONI L, Isensee K, VAldÉs L, editors. What are Marine Ecological Time Series telling us about the ocean? A status report. IOC-UNESCO, IOC Tech Ser. 129: 83-96.

NegRi R, Silva RI. 2003. Contribución de las distintas fracciones del fitoplancton a la biomasa fototrófica durante un ciclo anual en la estación EPEA ( $\left.38^{\circ} 28^{\prime} \mathrm{S}-57^{\circ} 41^{\prime} \mathrm{W}\right)$. V Jornadas Nacionales de Ciencias del Mar. Mar del Plata, Argentina. 147.

Negri R, SiLva RI. 2011. Estructura de la comunidad del fitoplancton en la estación costera EPEA durante el período 2000-2010 (provincia de Buenos Aires, Argentina). Bol Soc Argent Bot. 46 (Supl): 99-100.

O'Brien TD, López Urrutia A, Wiebe PH, Hay S. 2008. ICES Zooplankton Status Report 2006/2007. ICES Coop Res Rep. 292: 167 p.

O'Brien TD, LoRENZONi L, IsEnSEe K, VALdÉs L, editors. 2017. What are Marine Ecological Time Series telling us about the ocean? A status report. IOC-UNESCO, IOC Tech Ser. 129 $297 \mathrm{p}$.

O'Brien TD, Wiebe PH, Falkenhaug T, editors. 2013. ICES Zooplankton Status Report 2010/2011. ICES Coop Res Rep. 318: 208 p.

PAFFENHÖFER GA. 1993. On the ecology of marine cyclopoid copepods (Crustacea, Copepoda, Cyclopoida). J Plankton Res. 15: 37-55.

Penchaszadeh P. 1980. Ecología larvaria y reclutamiento del mejillón del Atlántico Surocci- 
dental, Mytilus platensis D’Orbigny. Cah Biol Mar. 21:169-179.

Pittois SG, Shaw M, Fox CJ, Frid CL. 2009. A new fine-mesh zooplankton time series from the Dove sampling station (North Sea). J Plankton Res. 31: 337-343.

Podestá GP, Brown OB, Evans RH. 1991. The annual cycle of satellite-derived sea surface temperature in the Southwestern Atlantic Ocean. American Meteorological Society. J Climate. 4: 157-467.

Purcell JE, Sturdevant MV, Galt CP. 2004. A review of appendicularians as prey of invertebrate and fish predators. In: GORSKY G, Youngbluth MJ, Deibel D, editors. Response of marine ecosystems to global change. Ecological impact of appendicularians. Paris: Editions des Archives Contemporaines. 359-435.

RAMÍREZ, FC. 1981. Zooplancton y producción secundaria. Parte I. Variación y distribución estacional de los copépodos. Contrib Inst Nac Invest Desarr Pesq (Mar del Plata) $\mathrm{N}^{\mathrm{o}} 383$ : 202-212.

REID PC, VALDÉS L. 2011. ICES status report on climate change in the North Atlantic. ICES Coop Res Rep. 310: 262 p.

Ribera D'Alcalá MR, Conversano F, Corato F, LiCANDRo P, MANGONi O, MARINO D, MAZzOCCHi MG, Modigh M, Motresor M, NarDELLA M, et al. 2004. Seasonal patterns in plankton communities in a pluriannual time series at a coastal Mediterranean site (Gulf of Naples): an attempt to discern recurrences and trends. Sci Mar. 68 (Suppl 1): 65-83.

Rice E, Stewart G. 2016. Decadal changes in zooplankton abundance and phenology of Long Island Sound reflect interacting changes in temperature and community composition. Mar Env Res. 120: 154-165.

RICHARDSON AJ. 2008. In hot water: zooplankton and climate change. ICES J Mar Sci. 65: 279295.

RISARO D. 2020 Las tendencias de largo plazo de la temperatura superficial del mar alrededor de Sudamérica y su posible impacto ecológico [PhD thesis]. Ciudad Autónoma de Buenos Aires: Facultad de Ciencias Exactas y Naturales, Universidad de Buenos Aires. 185 p.

Rodríguez F, FERnÁNDEZ E, HEAd RN, HARBOUR DS, Bratbak G, Heldal M, Harris RP. 2000. Temporal variability of viruses, bacteria, phytoplankton and zooplankton in the western English Channel off Plymouth. J Mar Biol Assoc UK. 80: 575-586.

Ruiz MG, Lutz VA, Segura V, Berghoff CF, NEgRI RM. 2020. The color of Epea: variability in the in situ bio-optical properties in the period 2000-2017. Mar Fish Sci. 33 (2): 205225.

SABAtini ME, Martos P. 2002. Mesozooplankton features in a frontal area off northern Patagonia (Argentina) during spring 1995 and 1998. Sci Mar. 66 (3): 215-232.

SÁNCHEZ RP, Ciechomski JD. 1995. Spawning and nursery grounds of pelagic fish species in the sea-shelf off Argentina and adjacent areas. Sci Mar. 59: 455-478.

Sarmiento JL, Slater R, Barber R, Bopp L, Doney SC, Hirst AC, Kleypas J, Matear R, Mikolajewicz U, Monfray P. et al. 2004. Response of ocean ecosystems to climate warming. Global Biogeochem. Cycles. 18: GB3003. doi:10.1029/2003GB002134

SATAPoomin S, Nielsen TG, Hansen PJ. 2004. Andaman-Sea copepods. Spatio-temporal variations in biomass and production and role in the pelagic food web. Mar Ecol Prog Ser. 274: 99-122.

SAto NE, Hernández D, Viñas MD. 2011a. Hábitos alimentarios de Sagitta friderici Ritter-Zahony, en las aguas costeras de la Provincia de Buenos Aires, Argentina. Bol Investig Mar Costeras. 40 (1): 59-74.

SATO NE, HERnÁNDEZ D, ViÑAs MD. 2011b. Hábitos alimentarios de las larvas de Engraulis anchoita (Hubbs \& Marini, 1935) en las aguas costeras de la Provincia de Buenos 
Aires, Argentina. Lat Am J Aquat Res. 39: 1624.

SiLVA RI. 2011. Dinámica del ultrafitoplancton en el Mar Argentino [PhD thesis]. Mar del Plata: Facultad de Ciencias Exactas y Naturales, Universidad Nacional de Mar del Plata. 187 p.

Silva RI, Negri RM, Lutz VA. 2009. Summer succession of ultraphytoplankton at the EPEA coastal station (Northern Argentina). J Plankton Res. 31 (4): 447-458.

SIMPSON JH. 1981. The shelf-sea fronts: implications of their existence and behavior. Phil Trans Roy Soc London A. 302: 531-546.

Siokou-Frangou I, Shiganova T, Christou ED, Kamburska L, Gubanova A, Konsulov A, Musaeva EI, Skryabin VA, Khoroshilov V. 2004. Mesozooplankton communities in the Aegean and Black seas: a comparative study. Mar Biol. 114: 111-126.

STATSOFT, Inc. 2007. STATISTICA (data analysis software system), version 8.0. www.statsoft. com.

Temperoni B, Viñas MD, Diovisalvi NR, Negri RM. 2011. Seasonal production of Oithona nana Giesbrecht, 1893 (Copepoda: Cyclopoida) in temperate coastal waters off Argentina. J Plankton Res. 33: 729-740.

Tönnesson K, MaAr M, Vargas C, Møller EF, Satapoomin S, Zervoudaki S, Christou E, Giannakourou A, Sell A, Petersen JK, et al. 2005. Grazing impact of Oikopleura dioica and copepods on an autumn plankton community. Mar Biol Res. 1: 365-373.

TURNER JT. 2004. The importance of small planktonic copepods and their roles in pelagic marine food webs. Zool Stud. 43: 255-266.

Uye S, Shibuno N. 1992. Reproductive biology of the planktonic copepod Paracalanus sp. in the Inland Sea of Japan. J Plankton Res. 14: 343-358.

VALDÉs L, LOMAS MW. 2017. New light for shipbased time series. In: O'BRIEN TD, LORENZONI L, Isensee K, ValdÉs L, editors. What are Marine Ecological Time Series telling us about the ocean? A status report. IOCUNESCO, IOC Tech Ser. 129: 11-17.

VIÑAS MD. 1990. Influence de la température sur la durée du développement d'Euterpina acutifrons (Copepoda: Harpacticoida) elevé au laboratoire. Mar Nat. 3: 29-35.

Viñas MD, Negri RM, CEPEDA GD, HeRnÁNDEZ D, Silva R, Daponte MC, Capitanio FL. 2013. Seasonal succession of zooplankton in coastal waters of the Argentine Sea (Southwest Atlantic Ocean): prevalence of classical or microbial food webs. Mar Biol Res. 9 (4): 371-382.

VIÑAS MD, RAMíreZ FC. 1996. Gut analysis of first-feeding anchovy larvae from Patagonian spawning area in relation to food availability. Arch Fish Mar Res. 43: 231-256.

Viñas MD, RAmírez FC, SANTOS B, Marrari M. 2007. Spatial and temporal distribution patterns of cladocerans in the Argentine Sea. Hydrobiologia. 594: 59-68.

Williams JA, Muxagata E. 2006. The seasonal abundance and production of Oithona nana Copepoda: Cyclopoida) in Southampton Water. J Plankton Res. 28: 1055-1065.

Zervoudaki S, Christou ED, Nielsen TG, Siokou-Frangou I, Assimakopoulou G, Giannakourou A, MaAr M, Pagou K, Krasakopoulou E, Christaki U, et al. 2007. The importance of small-sized copepods in a frontal area of the Aegean Sea. J Plankton Res. 29: 317-338. 